\title{
Selection Forces Driving Herding of Herbivorous Insect Larvae
}

\author{
Emma Despland* \\ Biology Department, Concordia University, Montréal, QC, Canada
}

Herding behavior is widespread among herbivorous insect larvae across several orders. These larval societies represent one of several different forms of insect sociality that have historically received less attention than the well-known eusocial model but are showing us that social diversity in insects is broader than originally imagined. These alternative forms of sociality often focus attention on the ecology, rather than the genetics, of sociality. Indeed, mutually beneficial cooperation among individuals is increasingly recognized as important relative to relatedness in the evolution of sociality, and I will explore its role in larval insect herds. Larval herds vary in in the complexity of their social behavior but what they have in common includes exhibiting specialized social behaviors that are ineffective in isolated individuals but mutually beneficial in groups. They hence constitute cooperation with direct advantages that doesn't require kinship between cooperators to be adaptive. Examples include: trail following, headto-tail processions and other behaviors that keep groups together, huddling tightly

OPEN ACCESS

Edited by:

Miriam H. Richards, Brock University, Canada

Reviewed by:

Donald Gray Miller III, California State University, Chico, United States Pablo Allen, University of Florida, United States

*Correspondence: Emma Despland Emma.Despland@concordia.ca

Specialty section: This article was submitted to Social Evolution,

a section of the journal Frontiers in Ecology and Evolution

Received: 18 August 2021 Accepted: 08 November 2021 Published: 07 December 2021

Citation:

Despland E (2021) Selection Forces Driving Herding of Herbivorous Insect Larvae.

Front. Ecol. Evol. 9:760806. doi: 10.3389/fevo.2021.760806 to bask, synchronized biting and edge-feeding to overwhelm plant defenses, silk production for shelter building or covering plant trichomes and collective defensive behaviors like head-swaying. Various selective advantages to group living have been suggested and I propose that different benefits are at play in different taxa where herding has evolved independently. Proposed benefits include those relative to selection pressure from abiotic factors (e.g., thermoregulation), to bottom-up pressures from plants or to top-down pressures from natural enemies. The adaptive value of herding cooperation must be understood in the context of the organism's niche and suite of traits. I propose several such suites in herbivorous larvae that occupy different niches. First, some herds aggregate to thermoregulate collectively, particularly in early spring feeders of the temperate zone. Second, other species aggregate to overwhelm host plant defenses, frequently observed in tropical species. Third, species that feed on toxic plants can aggregate to enhance the warning signal produced by aposematic coloration or stereotyped defensive behaviors. Finally, the combination of traits including gregariousness, conspicuous behavior and warning signals can be favored by a synergy between bottom-up and top-down selective forces. When larvae on toxic plants aggregate to overcome plant defenses, this grouping makes them conspicuous to predators and favors warning signals. I thus conclude that a single explanation is not sufficient for the broad range of herding behaviors that occurs in phylogenetically diverse insect larvae in different environments.

Keywords: caterpillars, cooperation, aggregation, group-living, gregarious, thermoregulation, social facilitation of feeding, aposematism 


\section{COOPERATION IN LARVAL HERDS}

Cooperation is said to occur when the behavior of one individual benefits others (West et al., 2021). This tends to lead to grouping as individuals stick together in order to accrue benefits from the actions of their neighbors. The essence of sociality has been described as "reciprocal communication of a cooperative nature" (Wilson, 1971), since, by definition, an individual can only incur benefits from remaining in a group if others remain there as well.

Kin selection has historically been considered the driving force in insect sociality, whereby individuals reap indirect fitness benefits by helping closely related kin. However, recent work has challenged this paradigm (Nowak et al., 2010), suggesting that direct fitness benefits can drive cooperation in insect groups, even among classically eusocial Hymenoptera (Hölldobler and Wilson, 2008; Leadbeater et al., 2011; Brahma et al., 2019). Direct benefits from natural selection that don't require kinship between cooperators are thus receiving increasing attention as an alternative framework for understanding insect sociality (Leimar and Hammerstein, 2010; West et al., 2021).

The broad diversity of social forms across multiple insect species provides valuable insights into the evolution and ecology of sociality beyond the hymenopteran eusocial continuum (Choe and Crespi, 1997; Costa, 2006; Rubenstein and Abbot, 2017); these have evolved independently and are likely driven by different selection pressures. This paper examines one phylogenetically widespread "alternative" form of insect sociality, herding of herbivorous insect larvae. This describes larval insects that aggregate and use a variety of mechanisms to remain together on their host plant, often gradually dispersing as they grow larger and becoming solitary as adults. Larval herds lack parentoffspring interaction and often include unrelated individuals (Costa, 2018) and thus challenge us to think beyond the eusocial model when considering insect sociality. They can provide unique insights into ecological drivers of sociality.

Herds often arise from the same egg mass and thus can be made up of siblings, suggesting the possibility for indirect benefits via kin selection. Indeed, cooperation is considered more likely to occur when population structure favors grouping of related individuals, due to indirect benefits that accrue from cooperating with relatives (Wilson, 1971). However, cooperation can be favored by natural selection if it is mutually beneficial and directly benefits the actor as well as recipients, whether they are related or not. Cooperation only appears paradoxical if it incurs a cost to the cooperator, which is not always the case (Leadbeater et al., 2011; Brahma et al., 2019). Indeed, recent work shows strong evidence for substantial direct benefits of cooperation in multiple animal taxa (West et al., 2021). Thus, although kin selection could play a role in favoring cooperation in larval herds, it is not necessarily required and direct benefits could provide more parsimonious explanations (Nowak et al., 2010). Existing evidence suggests that kin selection is not essential to promote herding: group mixing occurs in the few species in which the genetic structure of herds has been investigated, and no species studied to-date show any evidence of kin recognition (Costa, 2018).
This paper examines benefits of grouping in larval herds taking a direct fitness perspective, i.e., examining advantages to the individual of staying in the group vs. leaving. This approach remains neutral as to whether kin selection is involved, and focuses instead on the natural selection drivers of social behaviors. These occur independently of any putative indirect benefits. Evidence suggests that individual larvae weigh costs and benefits of remaining with the group and do leave herds when remaining becomes costly (Plenzich and Despland, 2018). Larval herding thus appears to be an instance where cooperation is mutually beneficial and hence where direct fitness benefits play an important role.

\section{NATURAL HISTORY OF LARVAL HERDS}

Larval gregariousness is observed in many insect species across several orders (Costa, 2006). The best studied species are Lepidopteran caterpillars, but examples are also known among sawfly (Hymenoptera) and beetle (Coleoptera) larvae and grasshopper (Orthoptera) nymphs. Many of these species clearly actively aggregate, rather than merely staying together following hatching on a high quality food source. There is no evidence for kin recognition in those species where it has been studied [caterpillars (Costa and Louque, 2001; Costa and Ross, 2003; Sun and Underwood, 2011) and sawflies (Terbot et al., 2017)]. Division of labor has been suggested in some species (Ghent, 1960; Underwood and Shapiro, 1999), but was not detected in others (Costa and Ross, 2003; McClure et al., 2011b) and does not seem to play a major role.

The mechanisms used by individuals to remain with the group have been studied in detail in several species, showing a range of sophisticated forms of communication whose main purpose appears to be keeping the group together (Despland, 2013). The best-known is pheromone trail following (see https: //alisonloader.com/mass-transit/ for an artist's manipulation of trail-following caterpillars by drawing artificial pheromone trails). This mechanism has been documented in caterpillars (Peterson, 1988; Roessingh, 1989; Fitzgerald, 1993b,a; Fitzgerald and Underwood, 1998; Ruf et al., 2001; Costa and Gotzek, 2003; Fitzgerald and Pescador-Rubio, 2011; Pescador-Rubio et al., 2011), beetle (Fitzgerald et al., 2004) and sawfly larvae (Costa and Louque, 2001). Other mechanism to maintain group cohesion include allomimesis (Despland et al., 2017) and processions (Fitzgerald, 2003) in caterpillars, and synchronization of movement (Despland and Simpson, 2006; Despland, 2020) in grasshopper nymphs. The existence of these behaviors underscores the benefits of cooperation, since they have clearly been shaped by natural selection to ensure that individuals do not get separated from the group (Hofmann et al., 2014).

Herding larvae exhibit various forms of social organization, generally categorized by different modes of foraging. Some larvae exhibit patch restricted foraging whereby the herd forms a shelter, often by spinning silk, and feed on the foliage enclosed within the shelter. Others are nomadic, using pheromone trails or other cues to move together between feeding sites. Some of the best studied species are central place foragers that build a 


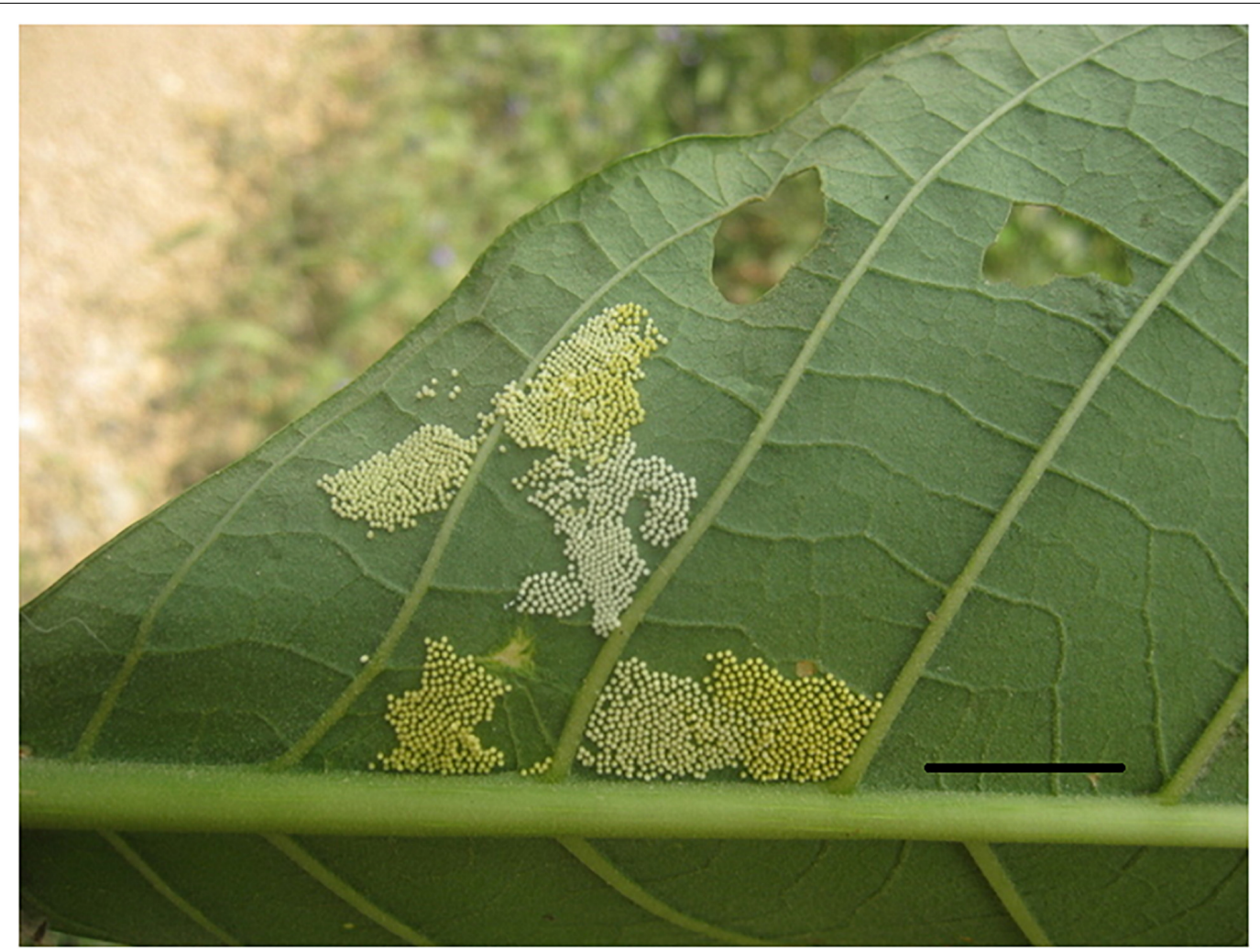

FIGURE 1 | Multiple clusters of Ithomia spp., eggs on a single leaf. Black bar indicates $1 \mathrm{~cm}$

shelter (again often using silk) then move out of the shelter to find food sources (Costa and Pierce, 1997; Fitzgerald and Costa, 1999). Broadening phylogenetic and geographic scope has shown myriad variations on these themes, including species that change between different organizational structures during larval development (Costa, 2006).

Most larval herds begin as sib-groups that emerge from the same egg mass, but fail to disperse. There are many reasons why herbivorous female insects might lay eggs in clusters on host plants, including constraints on the adult female (e.g., difficulty in host finding, short longevity), benefits to the eggs (e.g., protection from freezing or desiccation) and grouping of larval progeny once they emerge from the egg (Stamp, 1980). However, in many species that lay eggs in clusters, the larvae disperse upon hatching, suggesting that larval gregariousness can be selected for separately from egg-clustering.

At high population densities, larvae from different egg masses can fuse into large herds of multiple sib-groups (Costa and Ross, 2003; Fletcher, 2009). Indeed, some species preferentially lay eggs close to conspecific egg-masses (see Figure 1), presumably in order to increase group size (Stamp, 1980; Codella and Raffa, 1993). In the single species studied, this was shown to be adaptive due to the increase in group size despite the dilution of relatedness (Costa and Ross, 2003). Groups are often most cohesive early in caterpillar ontogeny, and caterpillars often disperse in the later instars, suggesting that benefits of grouping decrease as caterpillars grow larger (Despland and Hamzeh, 2004; Colasurdo and Despland, 2005; Despland and Huu, 2007). Herds can also dissolve under poor food conditions, as larvae move away to forage individually (Plenzich and Despland, 2018). The cost-benefit ratio of cooperation thus varies over larval ontogeny and in different environments (Guindre-Parker and Rubenstein, 2020).

Several different advantages to larval herding have been proposed in various insect species, and these can be grouped into broad categories based on the driving selection pressure: environmental pressures, bottom up forces from host plants, and top-down forces from natural enemies. I review these in the following sections and discuss contexts in which they might apply.

\section{ENVIRONMENTAL DRIVERS: THERMOREGULATION}

Insect larvae are poikilothermic and therefore suffer slower metabolism, growth and development at lower temperature. Several caterpillar species have been shown to reap thermal gains from collective basking (Table 1 and Figure 2) under conditions of relatively low temperature but high solar radiation. This cooperative thermoregulation sometimes includes the construction of a shelter or tent that can be used to further increase caterpillar body temperature (Table 1). 


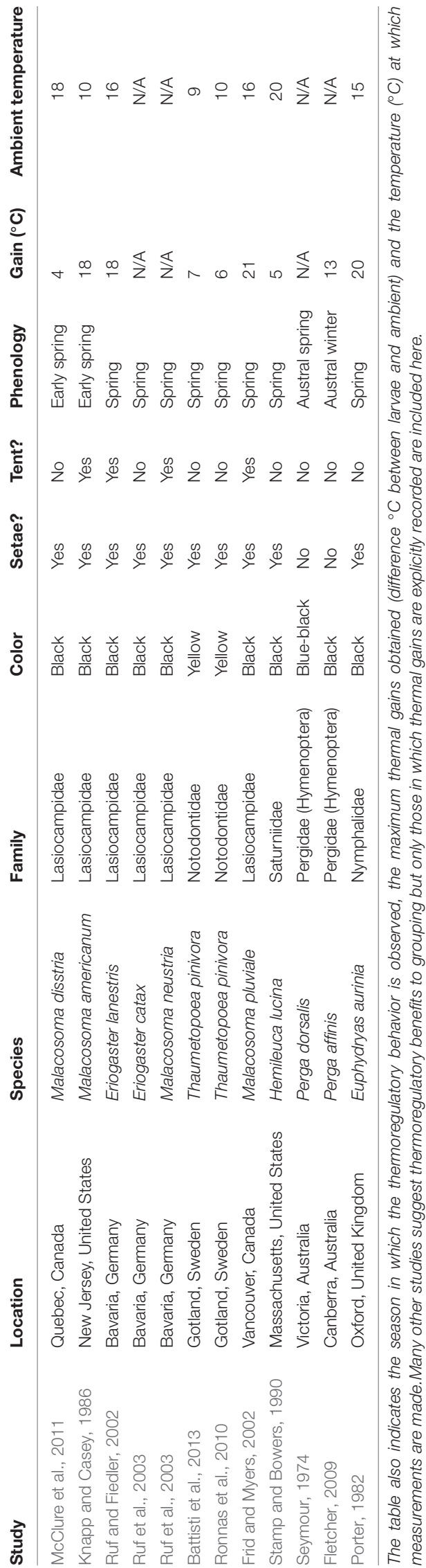

Larval grouping has also been suggested to facilitate physiological regulation by preventing water loss. Improved water balance has been shown in aggregations of Imbrasia belina (Westwood) (Saturniidae) caterpillars in South Africa (Klok and Chown, 1999) and Chlosyne lacinia (Geyer) (Nymphalidae) in Arizona (Clark and Faeth, 1997), as well as within the tents of Inachis io (Linnaeus, 1758) (Nymphalidae) in the United Kingdom (Willmer, 1980). However, no discernable effect of aggregation was shown on water loss in Eutrichia capensis (Lasiocampidae) in South Africa (Schoombie et al., 2013). It has been noted that insects feeding on foliage (which always has a high water content) are not likely to face great risk of desiccation except during periods of food deprivation (Klok and Chown, 1999).

Further investigation of species that show thermal gains in aggregations have shown that caterpillars can modulate their grouping behavior depending on ambient conditions. Caterpillars move to a basking spot under a heat lamp at low temperatures but not at high ones, and aggregation is tightest under conditions where it is most beneficial (low temperature and high solar radiation) (McClure et al., 2011a). Tent-builders move around inside the tent during the day to optimize temperature (Joos et al., 1988; Ruf and Fiedler, 2002; Ruf et al., 2003).

Many of the species that bask collectively to elevate body temperature are early spring feeders of the temperate zone (Table 1). These caterpillars hatch in early spring to feed on expanding foliage, which is generally softer and more nutritious than mature foliage (Despland, 2018) and to use the enemyfree space before many predators become active (Parry et al., 1998). However, these caterpillars emerge when temperatures are below optimal for growth and development, even below freezing (Despland, 2021), and many show adaptations that increase thermal gains from radiant solar energy: dark color, dense setae (Casey and Hegel, 1981), and collective basking.

A few notable well-documented biogeographical outliers include species that are active during winter in cool regions (Thaumatopoea pityocampa (Notodontidae) in the Mediterranean and Eucheira socialis (Pieridae) in Mexico) and cooperate to build tents to maximize solar radiation (Fitzgerald and Underwood, 2000; Uemura et al., 2020). As in the early-spring feeders above, these caterpillars are active at low, even below-freezing, temperatures, when cooperative thermoregulation is most advantageous.

Thermoregulation thus seems to have played an important role in shaping the biology of cold-weather active caterpillars, including their cooperative basking and shelter-building behavior (Joos et al., 1988; Joos, 1992; Despland, 2013). The beststudied among these are early-spring feeders in temperatezone-inhabiting members of the Lasiocampidae. Collective thermoregulatory behaviors are often associated with other traits like dark pigmentation and dense setae that also improve heat capture; cooperative thermoregulation is thus part of an adaptive suite of traits associated with the niche of early spring feeding that is particularly common among the Lasiocampidae. There are close to 2,000 species in the family; it is not known how many of these have gregarious larvae, nor are the phylogenetic 

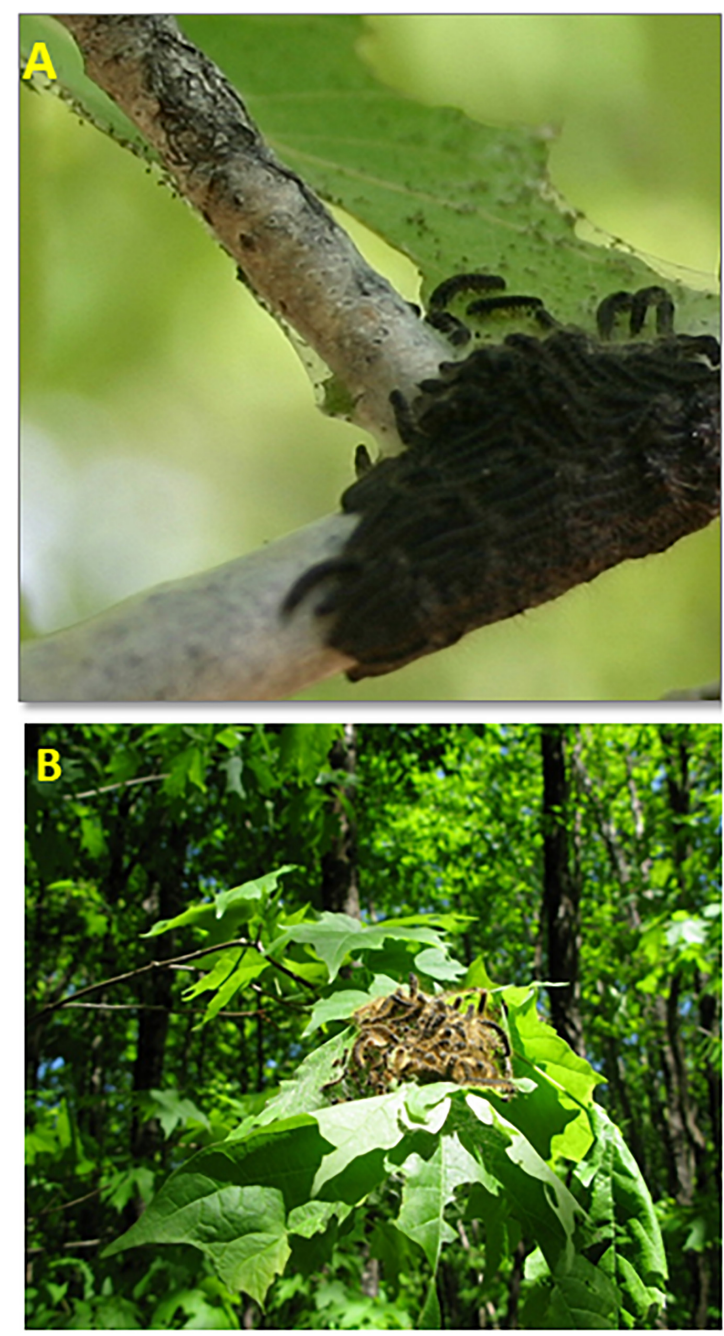

FIGURE 2 | Thermoregulatory cooperation: Malacosoma disstria (A) second instar (body length 1-1.5 cm) and (B) fifth instar (body length $>5 \mathrm{~cm}$ ) caterpillars basking collectively to increase body temperature in the boreal forest of Québec, Canada.

relationships between them clear (Regier et al., 2000; Zolotuhin et al., 2012). It has been suggested that gregarious larvae have evolved three separate times within the Lasiocampidae (Regier et al., 2000), but clearly much remains to be understood about the evolution of larval cooperation in this family and the role played by cooperative thermoregulation.

\section{BOTTOM-UP FORCES}

\section{Efficiency of Foraging}

Information sharing to optimize nutritional intake is thought to be a major driver of the evolution of sociality (Giraldeau and Caraco, 2000; Rubenstein and Abbot, 2017; Lihoreau et al., 2018). Collective foraging based on recruitment to pheromone trails is well-known to improve efficiency of food finding and exploitation by ants (Wilson, 1971; Hölldobler and Wilson, 2008). It therefore tends to become the default expectation for gregarious insects, especially those that use pheromone trails. Efficient collective foraging implies that individuals who find food recruit their colony-mates to the food source, and that strength of recruitment is modulated by food quality such that individuals are preferentially recruited to better quality sources (Dussutour et al., 2007; Lihoreau et al., 2018). Gregarious caterpillars, weevil and sawfly larvae use pheromone-marked silk trails to direct locomotion, but it is by no means evident that these trails improve the efficiency of foraging. Consistent choice of the better quality food source has only been demonstrated in the central-place foraging Lasiocampids Malacosoma americanum (Fitzgerald and Edgerly, 1979; Fitzgerald and Peterson, 1983; Fitzgerald, 1995) and Eriogaster lanestris (Ruf et al., 2001). By contrast, when a herd of the nomadic Malacosoma disstria are presented with a choice between two food sources, the entire group generally remains cohesive and moves together to one of the sources (Dussutour et al., 2008). The entire herd exploits whichever food source was discovered first (Dussutour et al., 2007), and often the second source isn't even sampled.

Indeed, $M$. disstria have been shown to trade-off selectivity in foraging for the advantages of staying together (Santana et al., 2015). Similarly, gregarious grasshopper nymphs [Chromacris psittacus (Romaleidae)] have been shown to remain feeding on the same leaf rather than sampling multiple leaves and exhibiting choice like the solitary adults of their species (Despland, 2020). Mathematical models suggest that cooperation via information sharing can improve individual foraging success when food is scarce and scattered (e.g., eusocial hymenopterans, seabirds), but that social interactions do not improve individual foraging when it is abundant and scattered, as is generally the case for herbivores (Giraldeau and Caraco, 2000; Rubenstein and Abbot, 2017). It seems that instead grouping imposes constraints on foraging, as it requires individuals to maintain contact and exchange information in order not to become separated from each other (Santana et al., 2015). These constraints can be minimized in central-place foragers by selective recruitment based on food quality, as occurs in M. americanum and E. lanestris. However, although selective recruitment has only been investigated in a few species, it does not appear to be widespread. Instead, increased costs associated with collective foraging constraints occurring under food limitation can lead to individuals ceasing to cooperate and to the break-up of groups (Plenzich and Despland, 2018).

\section{Overcoming Plant Defenses}

Another way in which gregarious insect larvae can cooperate is in overcoming plant defenses, either physical or chemical (see Figure 3). Indeed, herbivorous insects and plants engage in an evolutionary arms race, in which plants mount an array of defenses, including constitutive and inducible production of toxic, distasteful and/or glue-like compounds, toughness of foliage, trichomes on leaves to act as a mechanical barrier to small insects and trichomes containing toxic compounds to poison insects before they take their first bite. Herbivorous insects exhibit countermeasures, including various detoxification enzymes, sequestration of plant compounds, strong mandibles, 

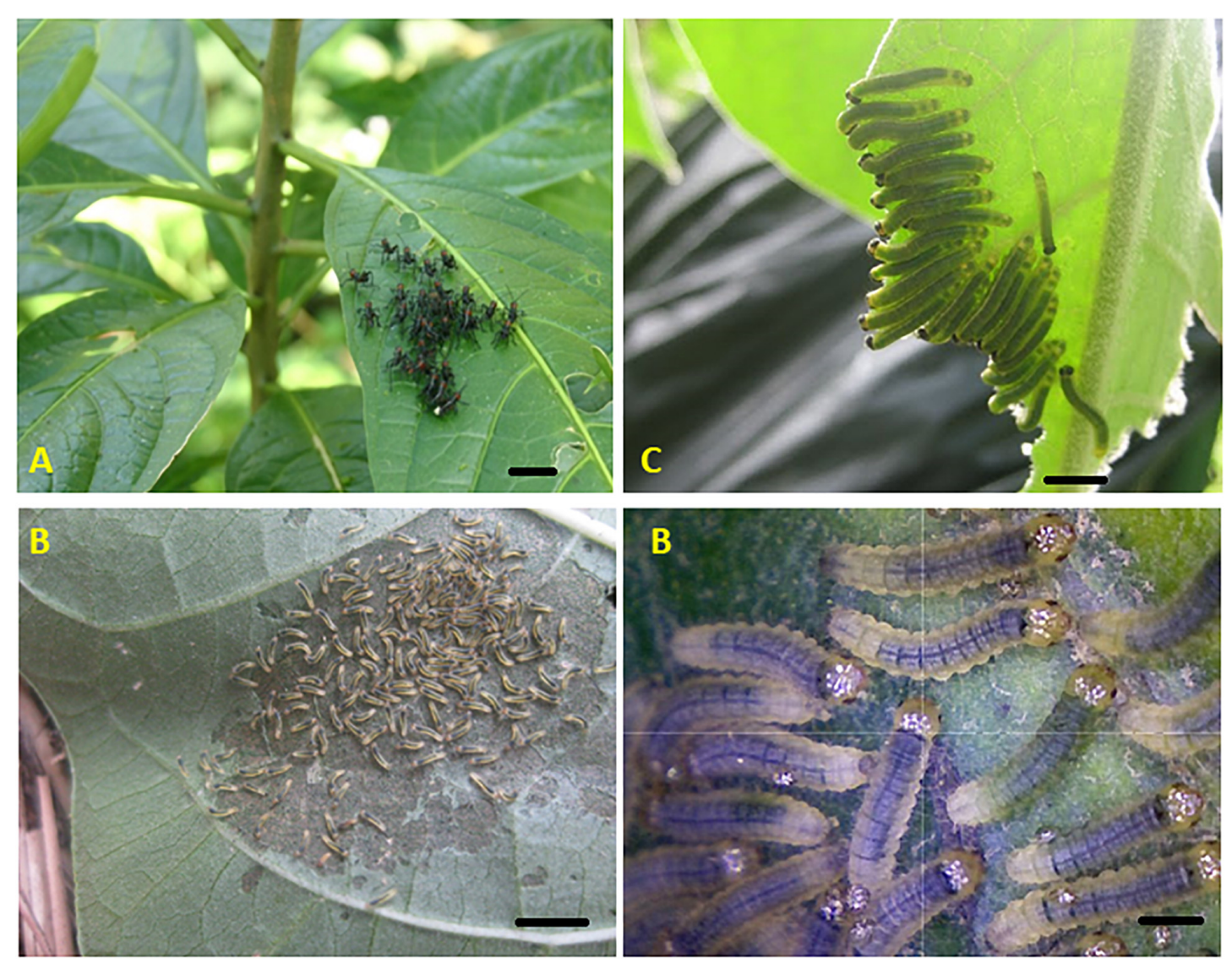

FIGURE 3 | Cooperation in overcoming plant defenses (bottom-up pressures): (A) synchronized feeding by Chromacris psittacus nymphs (Romaleidae), (B) collective leaf windowing by Pagyris cymothoe larvae, and (C) edge feeding by Ithomia larvae (both Ithomiini). All three species observed in secondary vegetation in cloud forest, Ecuador. Black bar in each panel indicates $1 \mathrm{~cm}$.

and even tarsal claws for climbing over trichomes (Despres et al., 2007). Gregarious larvae also use collaborative behaviors in response to plant defenses.

Multiple studies have shown that herbivorous insects reared at optimal temperatures in the absence of natural enemies grow faster and survive better in groups than alone (see Table 2), and have suggested various possible mechanisms for density-dependent manipulation of host quality by which grouping facilitates feeding on defended host plants. One possible mechanism is synchronous feeding to outpace and overwhelm production of induced chemical defenses (Denno and Benrey, 1997). Indeed, induced defenses are activated in plant tissues in response to herbivore biting, but this process takes time; hence herbivores can avoid these toxic compounds by feeding together on one leaf until induced defenses appear, then moving away on to an undamaged leaf (de Bobadilla et al., 2021). Mathematical modeling shows that this time-lag in induced defenses can lead mobile herbivores to aggregate, feed synchronously and move from induced to undamaged plant parts (Anderson et al., 2015). Other mechanisms by which insect larvae can collectively feed on plants inaccessible to isolated individuals include working together to initiate a feeding edge on tough foliage (Ghent,
1960; Nahrung et al., 2001), and collectively laying down silk to move over glandular trichomes without contacting the heads that contain toxins (Young and Moffett, 1979; Despland and Santacruz, 2020).

Social facilitation of feeding has been less well studied in gregarious larvae than has thermoregulation, but it also seems more prevalent in young larvae than in older larvae, presumably because larger individuals are better equipped to handle plant defenses. For instance, smaller larvae have smaller mandibles and are less able to chew tough leaves (Clissold, 2008; Nishida, 2010), are smaller relative to plant structures like trichomes (Despland and Santacruz, 2020), and have less well developed detoxification enzymes to handle plant defensive compounds (Despres et al., 2007).

Social facilitation of feeding on defended plants has also been observed more frequently in the tropics than has thermoregulation (Table 2), suggesting that benefits of cooperation in larval herds differ between environments. Indeed, the environmental factors that drive collective thermoregulation are often thought to be more limiting in highlatitude environments (Dobzhansky, 1950; Schemske, 2009). Conversely, trophic relationships and interspecific interactions 
TABLE 2 | List of studies demonstrating social facilitation of feeding, indicating the location and biome in which the study was conducted, the species and family of insect involved, the family of the plant on which assays were conducted and the reported mechanism.

\begin{tabular}{|c|c|c|c|c|c|c|}
\hline Study & Location & Biome & Species & Family & Host plant & Mechanism \\
\hline $\begin{array}{l}\text { Allen, 2010; } \\
\text { Nishida, } 2010\end{array}$ & Costa Rica & Rainforest & Euselasia chrysippe & Riodinidae & Melastomataceae & Feeding facilitation \\
\hline $\begin{array}{l}\text { Chang and } \\
\text { Morimoto, } 1988\end{array}$ & Japan & $\begin{array}{l}\text { Temperate } \\
\text { deciduous }\end{array}$ & $\begin{array}{l}\text { Gastrolina } \\
\text { depressa }\end{array}$ & $\begin{array}{l}\text { Coleoptera } \\
\text { Crysomelidae }\end{array}$ & Juglandaceae & Overcoming leaf toughness \\
\hline $\begin{array}{l}\text { Clark and Faeth, } \\
1997\end{array}$ & Arizona, United States & Desert & Chlosyne lacinia & Nymphalidae & Asteraceae & $\begin{array}{l}\text { Overcoming toughness and } \\
\text { trichomes }\end{array}$ \\
\hline $\begin{array}{l}\text { Denno and Benrey, } \\
1997\end{array}$ & Veracruz, Mexico & Rainforest & Chlosyne janais & Nymphalidae & Acanthaceae & $\begin{array}{l}\text { Overwhelming induced } \\
\text { chemical defenses }\end{array}$ \\
\hline Despland, 2019 & Mindo, Ecuador & $\begin{array}{l}\text { Secondary growth, } \\
\text { cloudforest }\end{array}$ & Mechanitis menapis & Nymphalidae, Ithomiini & Solanaceae & Silking trichomes \\
\hline Despland, 2020 & Mindo, Ecuador & $\begin{array}{l}\text { Secondary growth, } \\
\text { cloudforest }\end{array}$ & $\begin{array}{l}\text { Chromacris } \\
\text { psittacus }\end{array}$ & $\begin{array}{l}\text { Orthoptera: } \\
\text { Romaleidae }\end{array}$ & Solanaceae & Defensive chemistry \\
\hline $\begin{array}{l}\text { Fiorentino et al., } \\
2014\end{array}$ & Maryland, United States & $\begin{array}{l}\text { Temperate } \\
\text { deciduous forest }\end{array}$ & Acharia stimulea & Limacodidae & Fagaceae & Overcoming leaf toughness \\
\hline Fordyce, 2003 & California, United States & Chaparral & Battus philenor & Papilionidae & Aristolochiaceae & $\begin{array}{l}\text { Overwhelming induced } \\
\text { chemical defenses }\end{array}$ \\
\hline $\begin{array}{l}\text { Inouye and } \\
\text { Johnson, } 2005\end{array}$ & Costa Rica & $\begin{array}{l}\text { Secondary growth, } \\
\text { tropical dry forest }\end{array}$ & Chlosyne poecile & Nymphalidae & Acanthaceae & Silk \\
\hline Lawrence, 1990 & Virginia, United States & $\begin{array}{l}\text { Temperate } \\
\text { deciduous forest }\end{array}$ & Halisidota caryae & Arctiidae & $\begin{array}{l}\text { Fagaceae, } \\
\text { Juglandaceae, } \\
\text { Hamamelidaceae }\end{array}$ & Feeding facilitation \\
\hline $\begin{array}{l}\text { Mcmillin and } \\
\text { Wagner, } 1998\end{array}$ & Arizona, United States & Subalpine forest & $\begin{array}{l}\text { Neodiprion } \\
\text { autumnalis }\end{array}$ & $\begin{array}{l}\text { Hymenoptera: } \\
\text { Diprionidae }\end{array}$ & Pinaceae & Feeding facilitation \\
\hline $\begin{array}{l}\text { Nahrung et al., } \\
2001\end{array}$ & Tasmania, Australia & $\begin{array}{l}\text { Temperate moist } \\
\text { forest }\end{array}$ & $\begin{array}{l}\text { Chrysophtharta } \\
\text { agricola }\end{array}$ & $\begin{array}{l}\text { Coleoptera: } \\
\text { Chrysomelidae }\end{array}$ & Myrtaceae & $\begin{array}{l}\text { Initiating feeding on tough } \\
\text { leaves }\end{array}$ \\
\hline $\begin{array}{l}\text { Pescador-Rubio, } \\
2009\end{array}$ & Jalisco, Mexico & Dry tropical forest & Hylesia lineata & Saturniidae & $\begin{array}{l}\text { Erythroxylaceae, } \\
\text { Sapindaceae, } \\
\text { Salicaceae }\end{array}$ & Feeding facilitation \\
\hline $\begin{array}{l}\text { Rathcke and Poole, } \\
1975\end{array}$ & Maracay, Venezuela & Rainforest & $\begin{array}{l}\text { Mechanitis } \\
\text { polymnia isthmia }\end{array}$ & Nymphalidae, Ithomiini & Solanaceae & Silking trichomes \\
\hline $\begin{array}{l}\text { Reader and } \\
\text { Hochuli, } 2003\end{array}$ & NSW, Australia & $\begin{array}{l}\text { Dry sclerophyll } \\
\text { forest }\end{array}$ & Doratifera casta & Limacodidae & Myrtaceae & Feeding facilitation \\
\hline $\begin{array}{l}\text { Tsubaki and } \\
\text { Shiotsu, } 1982\end{array}$ & Kyushu, Japan & $\begin{array}{l}\text { Temperate } \\
\text { rainforest }\end{array}$ & Pryeria sinica & Zygaenidae & Celastraceae & $\begin{array}{l}\text { Overwhelming induced } \\
\text { chemical defenses }\end{array}$ \\
\hline $\begin{array}{l}\text { Young and Moffett, } \\
1979\end{array}$ & Costa Rica & $\begin{array}{l}\text { Secondary growth, } \\
\text { rainforest }\end{array}$ & $\begin{array}{l}\text { Mechanitis } \\
\text { polymnia isthmia }\end{array}$ & Nymphalidae, Ithomiini & Solanaceae & Silking trichomes \\
\hline Ghent, 1960 & Ontario, Canada & Boreal forest & Neodiprion pratti & $\begin{array}{l}\text { Hymenoptera: } \\
\text { Diprionidae }\end{array}$ & Pinaceae & $\begin{array}{l}\text { Initiating feeding on tough } \\
\text { leaves }\end{array}$ \\
\hline $\begin{array}{l}\text { Chang and } \\
\text { Morimoto, } 1988\end{array}$ & Nagano, Japan & $\begin{array}{l}\text { Temperate } \\
\text { deciduous forest }\end{array}$ & $\begin{array}{l}\text { Gastrolina } \\
\text { depressa }\end{array}$ & $\begin{array}{l}\text { Coleoptera: } \\
\text { Chrysomelidae }\end{array}$ & Juglandaceae & $\begin{array}{l}\text { Initiating feeding on tough } \\
\text { leaves }\end{array}$ \\
\hline
\end{tabular}

When no specific mechanism is described in the paper, this is left as "feeding facilitation." All species in the order Lepidoptera unless otherwise mentioned.

are considered more limiting in the biodiverse tropics, where bottom-up pressures from the plants at lower trophic levels appear important drivers of larval cooperation.

\section{TOP-DOWN FORCES}

\section{Anti-Predator Dilution Effect}

When prey animals aggregate, this satiates predators and dilutes individual predation risk (Codella and Raffa, 1993). This simple anti-predator defense was demonstrated in Neodiprion sertifer (Diprionidae) and M. disstria, in behavioral assays showing higher individual survival rate when groups rather than isolated individuals were exposed to a variety of predators, including ants, spiders, stinkbugs and parasitoid wasps (Codella and Raffa, 1993; McClure and Despland, 2011). However, this simple form of cooperation can be overridden by social predators that cooperate themselves, including paper wasps (McClure and Despland, 2010) and ants (Despland and Lessard, in press). Because workers forage for the entire colony and recruit nestmates to food finds, they do not satiate and can deplete entire caterpillar herds.

\section{Collective Anti-Predator Defenses}

Several species of herding larvae exhibit stereotyped collective behaviors in response to predator attacks that can be effective at repelling different enemies. Perhaps the best known example 

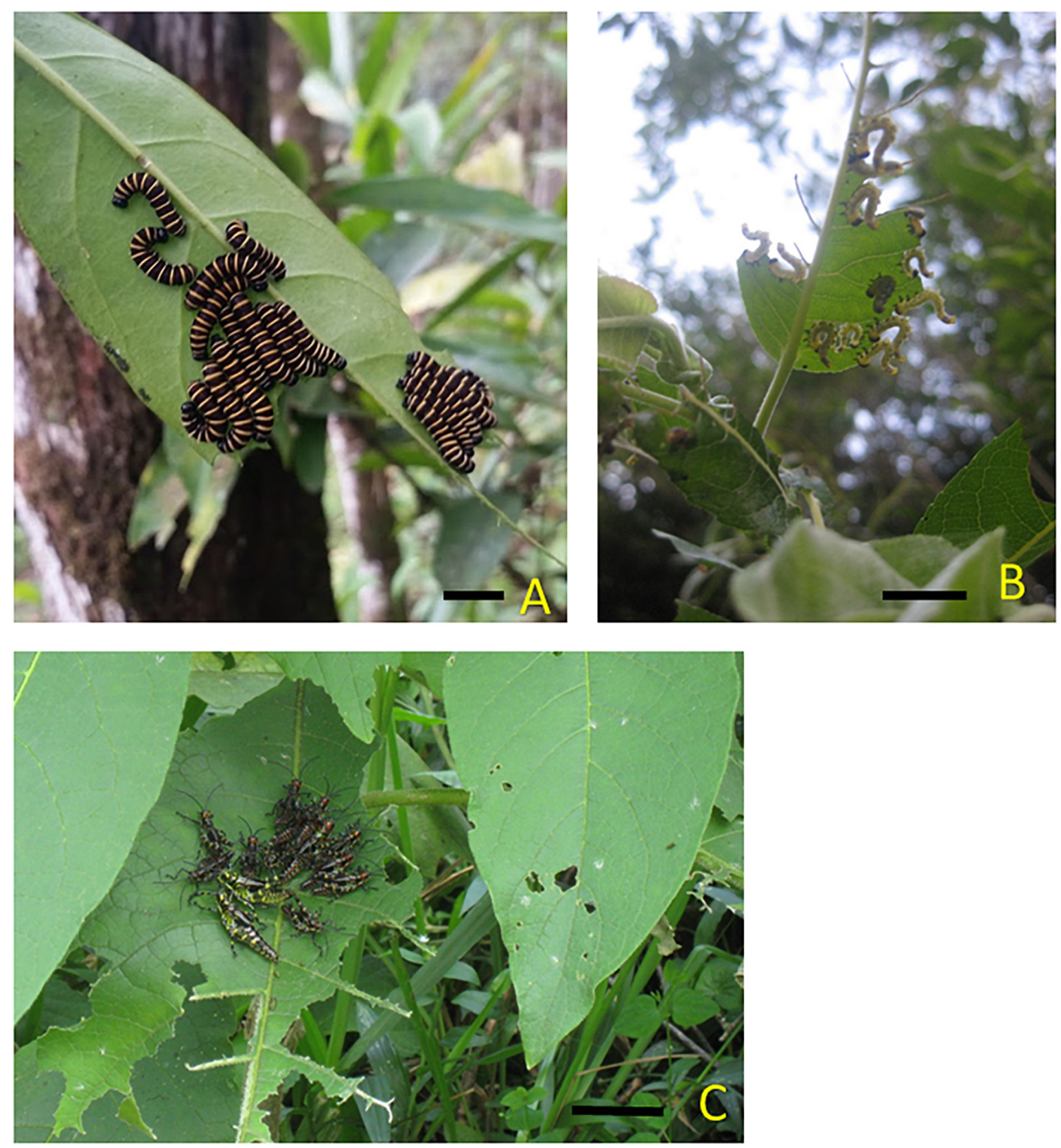

FIGURE 4 | Cooperation against predators (top-down pressures): (A) aposematic larvae of Methona confusa (Ithomiini) in secondary vegetation in cloud forest, Ecuador-photo credit Janeth Renteria, (B) collective defensive head-waving by Nematus spp., sawflies (Tenthredinidae) in boreal forest Québec, Canada, and (C) nymphs of Chromacris psittacus in secondary vegetation in cloud forest, Ecuador. Black bar in each panel indicates $1 \mathrm{~cm}$.

is the collective display exhibited by gregarious sawflies (see Figure 4) in which individuals synchronously rear up, wave their heads and regurgitate on predators (Codella and Raffa, 1993; Fletcher, 2009). Another striking example is cycloalexy exhibited by sawfly, chrysomelid, weevil and fly larvae (possibly also caterpillars and thrips): individuals position themselves in a circle with defensive organs facing outward (Dury et al., 2014). These behaviors are paired with effective defenses, including regurgitation and/or toxin secretion, and can both directly repel predators and act as warning signals (Codella and Raffa, 1993).

\section{Aposematism}

Many gregarious larvae exhibit bright colors that can act as a warning signal to deter predators. Aggregation amplifies this warning signal and indeed many gregarious larvae have bright colors (see Figure 4). It has also been suggested that the stereotypical synchronized behavioral displays of sawflies further 
amplify the aposematic signal (Codella and Raffa, 1993). Larval coloration can thus provide some indication as to the form of cooperation underlying the evolution of gregarious behavior: larvae that aggregate to become more apparent to predators tend to be brightly colored, whereas larvae that aggregate to thermoregulate tend to be black.

Gregarious brightly-colored larvae have been documented in Lepidoptera, Symphyta (Hymenoptera), Orthoptera and Chrysomelidae (Coleoptera) (Costa, 2006). Coloration is generally interpreted as aposematic, although this can be difficult to test explicitly (Caro and Ruxton, 2019) since aposematism requires that the animal be toxic or somehow unprofitable to predators and that the color act as a signal to predators. Many of these insect larvae do feed on plants with powerful chemical defenses and some are known to sequester these plant compounds and to be toxic to predators. Gregarious aposematic species appear to be common in the tropics (Codella and Raffa, 1993; Costa, 2006), supporting the idea that interspecies interactions are important drivers of larval herd cooperation in tropical regions.

\section{PATTERNS IN LARVAL COOPERATION}

\section{Phylogenetic and Biogeographical Patterns}

Larval herds thus exhibit a range of cooperative behaviors in response to abiotic stresses as well as to both bottom-up and top-down biotic pressures. The best-studied cooperative behavior is cooperative thermoregulation, including tent building. This has been most frequently described in early spring feeders of the temperate zone. However, group living is also frequent in tropical insect larvae, and in those species that have been studied, the benefits of gregarious behavior seem mostly associated with overcoming plant defenses or protection from predators. Indeed, larval herding appears to have evolved more than once in over 300 insect families (Costa, 2006), and the underlying selection pressures likely differ between environments and life history strategies.

Considerable evidence exists documenting the costs and benefits of cooperation in individual species, but these can vary within species according to individual ontogeny or physiological state (Guindre-Parker and Rubenstein, 2020), between related species with different ecologies and life histories and across major biomes. Within individual herding insect species, cooperation often breaks down as larvae grow larger and benefits decrease but costs associated with competition and pathogen transmission increase (Despland, 2013), or under food limitation when individuals leave the group to forage independently (Plenzich and Despland, 2018). However, ecological determinants of the costbenefit ratio of cooperation at the between-species level remain poorly understood (West et al., 2021). Thus, cost-benefit analyses could be applied across lineages like the Lasiocampidae, the Ithomiini (Nymphalidae), the Romaleidae and the Diprionidae that contain multiple species with gregarious larvae, exhibiting different group sizes, social organizations and individual color patterns. For instance, in the genus Malacosoma (Lasocampidae), some species are nomadic foragers ( $M$. disstria) whereas others form tents ( $M$. americanum and $M$. californicum pluviale), despite the fact that thermoregulation appears to be the main selection pressure driving herding behavior in all these species (see Table 1). Similarly, within the Ithomiini, Mechanitis menapis and Methona confusa live in small groups of approximately 10 individuals whereas Pagyris cymothoe and Ithomia spp. form much larger aggregations (Figures 1, 3, 4), and some of these larvae show typical aposematic coloration while others appear more cryptic (Figures 3, 4). Larval host plant specialization appears to have contributed to diversification in the Ithomiini (Willmott and Freitas, 2006), but the occurrence of larval herding across different species has not been documented or investigated in a phylogenetic context. One line of research to better understand the parallel evolution of larval cooperation would involve mapping patterns of social organization onto phylogenies of these taxa rich in gregarious larvae.

At the biogeographical level, broad patterns driving larval herding can be proposed: thermoregulation appears most important in the temperate zone, particularly in early springor even winter-feeders who face harsh abiotic conditions. By contrast, bottom-up and top-down biotic pressures more frequently drive larval cooperation in tropical species, in line with the long-standing theory that biotic interactions play the main role in driving evolutionary processes in the tropics (Dobzhansky, 1950; Schemske, 2009).

\section{Cooperation in Integrated Suites of Traits}

At the level of life history strategies, the best documented examples suggest that herding behavior is integrated within a suite of traits that together form a phenotype shaped by multiple selection pressures. One such adaptive suite of traits is seen in gregarious temperate-zone early-spring feeders, particularly in the family Lasiocampidae. These species emerge from diapause early in spring, when temperatures are low, to take advantages of high quality food and a relatively enemyfree space (Despland, 2018). They exhibit a suite of traits to counteract the associated low temperatures, including collective thermoregulation, dark coloration and dense setae (see Table 1). Another adaptive suite of traits is seen in tropical herding larvae, particularly in the Ithomiini and Romaleidae (Despland, 2020; Renteria et al.): a phenotype including gregariousness and feeding on toxic plants, which provides larvae with both competitor-free space and with the potential for sequestering toxins for their own defense. Another potential trait that would warrant further attention in these species is social immunity: does feeding on toxic plants protect larvae against pathogens (pharmacophagy) and help counter the higher disease risk associated with group-living (Costa, 2018)? Finally, this trait combination appears particularly frequent in early-succession or disturbed tropical habitats rather than in primary forest (Rathcke and Poole, 1975; Young and Moffett, 1979; Inouye and Johnson, 2005; Despland and Santacruz-Endara, 2016; Despland, 2020); and this habitat association would warrant further investigation.

Some gregarious species that feed on toxic plants are also brightly colored. Indeed, grouping, feeding on toxic plants 
and aposematic coloration together form a suite of traits that harnesses the advantages of toxic plants to avoid predation. Grouping and aposematism are frequently associated (Ruxton et al., 2019), and one potential evolutionary scenario, first proposed in locusts (Acrididae), suggests that insects feeding on toxic plants acquire warning color when bottom-up driven grouping makes crypsis impossible (Sword, 1999; Despland, 2005). Thus, the brightly colored nymphs of a Romaleid grasshopper are thought to remain in a herd to overcome plant defenses (see Table 2), and it's been suggested that this grouping facilitates the evolution of aposematism (Despland, 2020). A similar process could explain the behavior of diprionid sawflies: the chemically-defended larvae aggregate to overcome leaf toughness or to thermoregulate (Ghent, 1960; Fletcher, 2009) and adopt stereotyped behaviors including regurgitation and head-waving to warn predators that they are unprofitable prey (Codella and Raffa, 1993). Synergies between bottom-up and topdown pressures can thus help explain the evolution of herding in species where multiple benefits are observed (Fletcher, 2009). According to this scenario, cooperation that first evolved as an adaptation to overcome bottom-up plant defenses can also form part of an aposematic defensive phenotype that protects from top-down forces.

\section{CONCLUSION}

Among the evolutionary drivers underlying larval herding behavior, collective thermoregulation is reasonably wellestablished. However, although pressures from host plants and predators/parasitoids are often cited as important, they have received less critical analysis. In particular, further work on escaping induced plant defenses and on the relationship between grouping and warning signals could open up important new perspectives in the fields of plant-insect interactions and aposematic theory respectively.

It remains far from clear how collective feeding would allow larval insects to overcome or circumvent plant chemical defenses (see Table 2). One suggested mechanism is that insects feeding in synchrony maximize food intake before induced defenses become expressed (Anderson et al., 2015). The study of plant metabolic pathways underlying induced defense is a field that is progressing rapidly, which provides opportunities for investigating benefits to collective feeding at the molecular level [for example de Bobadilla et al. (2021)]. Improved understanding of these advantages could generate meaningful insights into the temporal and spatial feeding patterns of herbivores in general.

Similarly, many questions remain about how aposematism first evolved and how the costs and benefits of warning coloration depend on context (Ruxton et al., 2019). It is increasingly apparent that the adaptive value of color defenses must be understood in the context of suites of functionally related traits that tend to co-vary (Caro and Ruxton, 2019). Indeed, an organism's overall phenotype combines multiple traits and is a response to multiple selection pressures (Pigliucci, 2003). For instance, feeding on toxic plants, gregarious behavior and warning coloration are traits that are frequently expressed together, and that can also be associated with sluggishness, slow growth rate and conspicuous positioning (Despland, 2020). Physiological and biochemical traits related to detoxification, transformation and/or sequestration of plant compounds are likely also associated. Phenotypic integration (Pigliucci, 2003) implies that the adaptive value of each of these traits must be explored in the context of variation in the other functionally related traits. Investigating interactions between these traits and how they are shaped by both bottomup and top-down selection pressures could provide novel insights to the field of aposematic theory. More generally, applying the phenotypic integration approach to studying the different suites of traits that include larval herding (e.g., the thermoregulating early-spring feeders, the aposematic toxicplant eaters, etc.) could provide a useful framework to make sense of the complex diversity of social behaviors of herbivorous insect larvae.

In conclusion, this paper shows abundant evidence for direct benefits to larval herding, suggesting that kin selection is not required to explain why hatching insect siblings aggregate. It is worth mentioning that this does not shed any light on the question of whether kin selection occurs as well, since kin selection and natural selection can operate as independent processes (West et al., 2021). Theoretical models of the evolution of insect sociality also examine the potential roles of various levels of selection, raising the possibility that selection could operate on the whole group as well as on the individual (Traulsen and Nowak, 2006; Hölldobler and Wilson, 2008). Indeed, interactions between group members can generate emergent group-level traits that influence individual survival (Wellington, 1960; Myers, 2000): for instance in E. lanestris, maintenance of an intact tent is the best predictor of survival of at least one individual of a group (Ruf and Fiedler, 2005). Larval herds thus provide a model system amenable to examining group-level selection, one that is perhaps particularly tractable due to its simple demographic structure.

Finally, it must be noted that only a small minority of herding larvae have been studied and therefore it would be premature to generalize about selective drivers of this alternative yet surprisingly widespread form of insect sociality. Tropical species in particular exhibit a wide range of striking collective behaviors that remain uninvestigated, and for which we can at present only speculate as to their function: for example, rolling swarm caterpillars ${ }^{1}$ or wriggling bunches of sawfly larvae $^{2}$. The temperate zone bias (Zuk, 2016) applies to the study of cooperative behavior in insect larvae as well as to other areas of ecology, and implies that there remains much to be discovered.

\footnotetext{
${ }^{1}$ https://www.wired.com/2013/07/why-are-these-caterpillarsclimbing-over-each-other-the-surprising-science-behind-the-swarm/ ${ }^{2}$ http://www.storytrender.com/24762/social-sawflies-band-together-strangedefense-mechanism/
}

\section{AUTHOR CONTRIBUTIONS}

ED wrote the manuscript. 


\section{REFERENCES}

Allen, P. E. (2010). Group size effects on survivorship and adult development in the gregarious larvae of Euselasia chrysippe (Lepidoptera, Riodinidae). Insectes Soc. 57, 199-204. doi: 10.1007/s00040-010-0068-3

Anderson, K. E., Inouye, B. D., and Underwood, N. (2015). Can inducible resistance in plants cause herbivore aggregations? Spatial patterns in an inducible plant/herbivore model. Ecology 96, 2758-2770. doi: 10.1890/141697.1

Battisti, A., Marini, L., Pitacco, A., and Larsson, S. (2013). Solar radiation directly affects larval performance of a forest insect. Ecol. Entomol. 38, 553-559. doi: 10.1111/een.12047

Brahma, A., Mandal, S., and Gadagkar, R. (2019). To leave or to stay: direct fitness through natural nest foundation in a primitively eusocial wasp. Insect. Soc. 66, 335-342. doi: 10.1007/s00040-019-00702-2

Caro, T., and Ruxton, G. (2019). Aposematism: unpacking the Defences. Trends Ecol. Evol. 34, 595-604. doi: 10.1016/j.tree.2019.02.015

Casey, T. M., and Hegel, J. R. (1981). Caterpillar Setae: insulation for an Ectotherm. Science 214, 1131-1133. doi: 10.1126/science.214.4525.1131

Chang, K.-S., and Morimoto, N. (1988). Life table studies of the walnut leaf beetle, Gastrolina depressa (Coleoptera: Chrysomelidae), with special attention to aggregation. Popul. Ecol. 30, 297-313. doi: 10.1007/BF02513251

Choe, J. C., and Crespi, B. J. (eds) (1997). The Evolution of Social Behavior in Insects and Arachnids. Cambridge: Cambridge University Press.

Clark, B. R., and Faeth, S. H. (1997). The consequences of larval aggregation in the butterfly Chlosyne lacinia. Ecol. Entomol. 22, 408-415. doi: 10.1046/j.13652311.1997.00091.x

Clissold, F. (2008). "The biomechanics of chewing and plant fracture: mechanisms and implications" in Advances in Insect Physiology: insect Mechanics and Control. eds J. Casas and S. J. Simpson (London: Academic Press). 317-372. doi: 10.1016/s0065-2806(07)34006-x

Codella, S., and Raffa, K. (1993). "Defense Strategies of Folivorous Sawflies" in Sawfly Life History Adaptations to Woody Plants. eds M. Wagner and K. Raffa. (London: Academic Press). 261-294.

Colasurdo, N., and Despland, E. (2005). Social cues and following behavior in the forest tent caterpillar. J. Insect Behav. 18, 77-87. doi: 10.1007/s10905-0059348-6

Costa, J. T. (2006). The Other Insect Societies. Cambridge: Belknap Press.

Costa, J. T. (2018). The other insect societies: overview and new directions. Curr. Opin. Insect Sci. 28, 40-49. doi: 10.1016/j.cois.2018.04.008

Costa, J. T., and Gotzek, D. A. (2003). Late-instar shift in foraging strategy and trail pheromone use by caterpillars of the neotropical moth Arsenura armida (Cramer)(Saturniidae: arsenurinae). Journal of the Lepidopterists'. Society 57:220.

Costa, J. T., and Louque, R. W. (2001). Group foraging and trail following behavior of the red-headed pine sawfly Neodiprion lecontei (Fitch) (Hymenoptera: Symphyta: Diprionidae). Ann. Entomol. Soc. Am. 94, 480-489. doi: 10.1603/ 0013-8746(2001)094[0480:gfatfb]2.0.co;2

Costa, J. T., and Pierce, N. E. (1997). "Social evolution in the Lepidoptera: ecological context and communication in larval societies" in The Evolution of Social Behaviour in Insects and Arachnids. eds J. C. Choe and B. J. Crespi (Cambridge: Cambridge University Press). 407-442. doi: 10.1017/ cbo9780511721953.021

Costa, J. T., and Ross, K. G. (2003). Fitness effects of group merging in a social insect. Proc. R. Soc. Lond. B 270, 1697-1702. doi: 10.1098/rspb.2003. 2422

de Bobadilla, M. F., Van Wiechen, R., Gort, G., and Poelman, E. H. (2021). Plasticity in Induced Resistance to Sequential Attack by Multiple Herbivores in Brassica nigra. Netherlands: Wageningen University \& Research. doi: 10.21203/rs.3.rs$170192 / \mathrm{v} 1$

Denno, R. F., and Benrey, B. (1997). Aggregation facilitates larval growth in the neotropical nymphalid butterfly Chlosyne janais. Ecol. Entomol. 22, 133-141. doi: 10.1046/j.1365-2311.1997.t01-1-00063.x

Despland, E. (2005). Diet breadth and anti-predator strategies in desert locusts and other Orthopterans. J. Orthoptera Res. 14, 227-233. doi: 10.1665/10826467(2005)14[227:dbaasi]2.0.co;2

Despland, E. (2013). Plasticity of collective behavior in a nomadic early spring folivore. Front. Physiol. 4:54. doi: 10.3389/fphys.2013.00054
Despland, E. (2018). Effects of phenological synchronization on caterpillar earlyinstar survival under a changing climate. Can. J. For. Res. 58, 247-254. doi: 10.1139/cjfr-2016-0537

Despland, E. (2019). Caterpillars cooperate to overcome plant glandular trichome defenses. Front. Ecol. Evol. 7:232. doi: 10.3389/fevo.2019.00232

Despland, E. (2020). Ontogenetic shift from aposematism and gregariousness to crypsis in a Romaleid grasshopper. PLoS One 15:e0237594. doi: 10.1371/ journal.pone.0237594

Despland, E. (2021). Ces fourmis que cache la forêt. Couvert. Boréal. 17:11.

Despland, E., and Hamzeh, S. (2004). Ontogenetic changes in social behaviour in the forest tent caterpillar, Malacosoma disstria. Behav. Ecol. Sociobiol. 56, 177-184.

Despland, E., and Huu, A. L. (2007). Pros and cons of group-living in the forest tent caterpillar: separating the roles of silk and of grouping. Entomol. Exp. Appl. 122, 181-189. doi: 10.1111/j.1570-7458.2006.00512.x

Despland, E., and Lessard, J.-P. (in press). Social Predation by Ants as a Mortality Source for an Arboreal Gregarious Forest Pest.

Despland, E., and Santacruz, P. G. (2020). Top-down and bottom-up controls on an herbivore on a native and introduced plant in a tropical agricultural landscape. PeerJ. 8:e8782. doi: 10.7717/peerj.8782

Despland, E., and Santacruz-Endara, P. (2016). Silk drives aggregation and following in the neotropical Ithomiine caterpillar Mechanitis menapis. Physiol. Entomol. 41, 274-280.

Despland, E., and Simpson, S. J. (2006). Resource distribution mediates synchronization of physiological rhythms in locust groups. Proc. R. Soc. B 273, 1517-1522. doi: 10.1098/rspb.2006.3471

Despland, E., Gervais, D., and Morcos, L. (2017). Double allomimesis of advancing and retreating individuals maintains cohesion in exploring groups of nomadic caterpillars. Behav. Ecol. Sociobiol. 71:56.

Despres, L., David, J. P., and Gallet, C. (2007). The evolutionary ecology of insect resistance to plant chemicals. Trends Ecol. Evol. 22:298. doi: 10.1016/j.tree.2007. 02.010

Dobzhansky, T. (1950). Evolution in the tropics. Am. Sci. 38, 209-221.

Dury, G., Bede, J., and Windsor, D. (2014). Preemptive Circular Defence of Immature Insects: definition and Occurrences of Cycloalexy Revisited. Psyche J. Entomol. 2014, 1-13. doi: 10.1155/2014/642908

Dussutour, A., Nicolis, S. C., Despland, E., and Simpson, S. J. (2008). Individual differences influence collective behaviour in social caterpillars. Anim. Behav. 76, 5-16.

Dussutour, A., Simpson, S. J., Despland, E., and Colasurdo, N. (2007). When the group denies individual nutritional wisdom. Anim. Behav. 74, 931-939.

Fiorentino, V. L., Murphy, S. M., Stoepler, T. M., and Lill, J. T. (2014). Facilitative effects of group feeding on performance of the saddleback caterpillar (Lepidoptera: Limacodidae). Environ. Entomol. 43, 131-138. doi: 10.1603/ EN13144

Fitzgerald, T. D. (1993a). Trail and Arena Marking By Caterpillars of Archips cerasivoranus (Lepidoptera, Tortricidae). J. Chem. Ecol. 19, 1479-1489. doi: 10.1007/BF00984891

Fitzgerald, T. D. (1993b). Trail Following and Recruitment - Response of Eastern Tent Caterpillar Malacosoma americanum to 5-Beta-Cholestane-3,24- Dione and 5-Beta-Cholestan-3-One. J. Chem. Ecol. 19, 449-457. doi: 10.1007/ BF00994318

Fitzgerald, T. D. (1995). The Tent Caterpillars. Ithaca: Cornell University Press.

Fitzgerald, T. D. (2003). Role of trail pheromone in foraging and processionary behavior of pine processionary caterpillars Thaumetopoea pityocampa. J. Chem. Ecol. 29, 513-532. doi: 10.1023/a:1022875102682

Fitzgerald, T. D., and Costa, J. T. (1999). "Collective behavior in social caterpillars" in Information Processing in Social Insects. eds C. Detrain, J. L. Deneubourg, and J. M. Pasteels (Basel: Birkhauser Verlag). 379-400. doi: 10.1007/978-3-03488739-7_20

Fitzgerald, T. D., and Edgerly, J. S. (1979). Exploration and Recruitment in Field Colonies of Eastern Tent Caterpillars. J. Geor. Entomol. Soc. 14, 312-314.

Fitzgerald, T. D., and Peterson, S. C. (1983). Elective recruitment communication by the eastern tent caterpillar (Malacosoma americanum). Anim. Behav. 31, 417-423.

Fitzgerald, T. D., and Underwood, D. L. A. (1998). Trail marking by the larva of the madrone butterfly Eucheira socialis and the role of the trail pheromone in communal foraging behavior. J. Insect Behav. 11, 247-263. 
Fitzgerald, T. D., and Underwood, D. L. A. (2000). Winter foraging patterns and voluntary hypothermia in the social caterpillar Eucheira socialis. Ecol. Entomol. $25,1-10$.

Fitzgerald, T. D., Pescador-Rubio, A., Turna, M. T., and Costa, J. T. (2004). Trail marking and processionary behavior of the larvae of the weevil Phelypera distigma (Coleoptera: curculionidae). J. Insect Behav. 17, 627-646. doi: 10.1023/ b:joir.0000042545.83981.1b

Fitzgerald, T., and Pescador-Rubio, A. (2011). Trail Marking and Abandonment of Depleted Feeding Sites by the Caterpillars of Eutachyptera psidii (Lepidoptera: lasiocampidae). J. Insect Behav. 24, 380-392.

Fletcher, L. E. (2009). Examining potential benefits of group living in a sawfly larva, Perga affinis. Behav. Ecol. 20, 657-664.

Fordyce, J. A. (2003). Aggregative feeding of pipevine swallowtail larvae enhances hostplant suitability. Oecologia 135, 250-257. doi: 10.1007/s00442-003-1177-8

Frid, L., and Myers, J. H. (2002). Thermal ecology of western tent caterpillars Malacosoma californicum pluviale and infection by nucleopolyhedrovirus. Ecol. Entomol. 27, 665-673.

Ghent, A. W. (1960). A study of the Group-feeding Behaviour of Larvae of the Jack Pine Sawfly, Neodiprion Pratti Banksianae Roh. Netherlands: Brill Publishers. 110-148.

Giraldeau, L. A., and Caraco, T. (2000). Social Foraging Theory. Princeton: Princeton University Press.

Guindre-Parker, S., and Rubenstein, D. R. (2020). Survival Benefits of Group Living in a Fluctuating Environment. Am. Nat. 195, 1027-1036. doi: 10.1086/708496

Hofmann, H. A., Beery, A. K., Blumstein, D. T., Couzin, I. D., Earley, R. L., Hayes, L. D., et al. (2014). An evolutionary framework for studying mechanisms of social behavior. Trends Ecol. Evol. 29, 581-589. doi: 10.1016/j.tree.2014.07.008

Hölldobler, B., and Wilson, E. O. (2008). The Superorganism. Norton. Available online at: https://wwnorton.com/books/9780393067040 [Accessed October 5, 2021].

Inouye, B. D., and Johnson, D. M. (2005). Larval aggregation affects feeding rate in Chlosyne poecile (Lepidoptera: nymphalidae). Florida Entomol. 88, 247-252. doi: 10.1653/0015-4040(2005)088[0247:laafri]2.0.co;2

Joos, B. (1992). Adaptations for locomotion at low body temperatures in eastern tent caterpillars, Malacosoma americanum. Physiol. Zool. 65, 1148-1161. doi: 10.1086/physzool.65.6.30158273

Joos, B., Casey, T. M., Fitzgerald, T. D., and Buttemer, W. A. (1988). Roles of the tent in behavioral thermoregulation of eastern tent caterpillars. Ecology 69, 2004-2011. doi: 10.2307/1941178

Klok, C. J., and Chown, S. L. (1999). Assessing the benefits of aggregation: thermal biology and water relations of anomalous Emperor Moth caterpillars. Funct. Ecol. 13, 417-427.

Knapp, R., and Casey, T. M. (1986). Thermal ecology, behavior, and growth of gypsy moth and eastern tent caterpillars. Ecology 67, 598-608.

Lawrence, W. S. (1990). The effects of group size and host species on development and survivorship of a gregarious caterpillar Halisidota caryae (Lepidoptera: Arctiidae). Ecol. Entomol. 15, 53-62. doi: 10.1111/j.1365-2311.1990.tb00783.x

Leadbeater, E., Carruthers, J. M., Green, J. P., Rosser, N. S., and Field, J. (2011). Nest Inheritance Is the Missing Source of Direct Fitness in a Primitively Eusocial Insect. Science 333, 874-876. doi: 10.1126/science. 1205140

Leimar, O., and Hammerstein, P. (2010). Cooperation for direct fitness benefits. Philos. Transac. R. Soc. B Biol. Sci. 365, 2619-2626. doi: 10.1098/rstb.2010.0116

Lihoreau, M., Gomez-Moracho, T., Pasquaretta, C., Costa, J. T., and Buhl, J. (2018). Social nutrition: an emerging field in insect science. Curr. Opin. Insect Sci. 28, 73-80. doi: 10.1016/j.cois.2018.05.003

McClure, M., and Despland, E. (2010). Collective foraging pattern of field colonies of Malacosoma disstria caterpillars. Can. Entomol. 142, 473-480.

McClure, M., and Despland, E. (2011). Defensive responses by a social caterpillar are tailored to different predators and change with larval instar and group size. Naturwissenschaften 98, 425-434. doi: 10.1007/s00114-011-0788-x

McClure, M., Cannell, E., and Despland, E. (2011). Thermal ecology and behavior of the nomadic social forager, Malacosoma disstria. Physiol. Entomol. 36, 120-127.

McClure, M., Cannell, E., and Despland, E. (2011a). Thermal ecology and behavior of the nomadic social forager, Malacosoma disstria. Physiol. Entomol. 36, $120-127$.

McClure, M., Ralph, M., and Despland, E. (2011b). Group leadership depends on energetic state in a nomadic collective foraging caterpillar. Behav. Ecol. Sociobiol. 65, 1573-1579. doi: 10.1007/s00265-011-1167-5
Mcmillin, J. D., and Wagner, M. R. (1998). Influence of host plant vs. natural enemies on the spatial distribution of a pine sawfly, Neodiprion autumnalis. Ecol. Entomol. 23, 397-408. doi: 10.1046/j.1365-2311.1998.00146.x

Myers, J. (2000). Population fluctuations of the western tent caterpillar in southwestern British Columbia. Popul. Ecol. 42, 231-241. doi: 10.1007/ pl00012002

Nahrung, H. F., Dunstan, P. K., and Allen, G. R. (2001). Larval gregariousness and neonate establishment of the eucalypt-feeding beetle Chrysophtharta agricola (Coleoptera: chrysomelidae: paropsini). Oikos 94, 358-364. doi: 10.1034/j. 1600-0706.2001.940217.x

Nishida, K. (2010). Description of the immature stages and life history of Euselasia (Lepidoptera: riodinidae) on Miconia (Melastomataceae) in Costa Rica. Zootaxa 2466, 1-74. doi: 10.11646/zootaxa.2466.1.1

Nowak, M. A., Tarnita, C. E., and Wilson, E. O. (2010). The evolution of eusociality. Nature 466, 1057-1062. doi: 10.1038/nature09205

Parry, D., Spence, J. R., and Volney, W. J. A. (1998). Budbreak phenology and natural enemies mediate survival of first-instar forest tent caterpillar (Lepidoptera: lasiocampidae). Environ. Entomol. 27, 1368-1374. doi: 10.1093/ ee/27.6.1368

Pescador-Rubio, A. (2009). Growth and survival of a tropical polyphagous caterpillar: effects of host and group size. Southwest. Entomol. 34, 75-84. doi: 10.3958/059.034.0107

Pescador-Rubio, A., Gerardo, S., Paez-Gerardo, L., Ramirez-Reyes, A. J., IbarraJimenez, R. A., and Fitzgerald, T. (2011). Trail Marking by Caterpillars of the Silverspot Butterfly Dione juno huascuma. J. Insect Sci. 11:55. doi: 10.1673/031. 011.5501

Peterson, S. C. (1988). Chemical trail marking and folowing by caterpillars of Malacosoma neustria. J. Chem. Ecol. 14, 815-824. doi: 10.1007/BF01018775

Pigliucci, M. (2003). Phenotypic integration: studying the ecology and evolution of complex phenotypes. Ecol. Lett. 6, 265-272. doi: 10.1046/j.1461-0248.2003. 00428.x

Plenzich, C., and Despland, E. (2018). Host-plant mediated effects on group cohesion and mobility in a nomadic gregarious caterpillar. Behav. Ecol. Sociobiol. 72, 1-7.

Porter, K. (1982). Basking behaviour in larvae of the butterfly Euphydryas aurina. Oikos 38, 308-312. doi: 10.2307/3544670

Rathcke, B. J., and Poole, R. W. (1975). Coevolutionary race continues: butterfly larval adaptation to plant trichomes. Science 187, 175-176. doi: 10.1126/ science.187.4172.175

Reader, T., and Hochuli, D. (2003). Understanding gregariousness in a larval lepidopteran: the roles of host plant, predation, and microclimate. Ecol. Entomol. 28, 729-737. doi: 10.1111/j.1365-2311.2003.00560.x

Regier, J. C., Mitter, C., Peigler, R. S., and Friedlander, T. P. (2000). Phylogenetic relationships in Lasiocampidae (Lepidoptera): initial evidence from elongation factor-1 $\alpha$ sequences. Insect Syst. and Evol. 31, 179-186. doi: 10.1163/ 187631200x00372

Renteria, J., Despland, E., and Checa, M. F. (in press). Does group-living influence growth and survival of Methona confusa larvae (Lepidoptera: Nymphalidae, Ithomiinae). Trop. Lepid. Res.

Roessingh, P. (1989). The trail following behaviour of Yponomeuta cagnagellus. Entomol. Exp. Appl. 51, 49-57. doi: 10.1111/j.1570-7458.1989.tb 01213.x

Ronnas, C., Larsson, S., Pitacco, A., and Battisti, A. (2010). Effects of colony size on larval performance in a processionary moth. Ecol. Entomol. 35, 436-445.

Rubenstein, D. R., and Abbot, P. (2017). Comparative Social Evolution. Cambridge: Cambridge University Press.

Ruf, C., and Fiedler, K. (2002). Tent-based thermoregulation in social caterpillars of Eriogaster lanestris (Lepidoptera: lasiocampidae): behavioral mechanisms and physical features of the tent. J. Ther. Biol. 27, 493-501.

Ruf, C., and Fiedler, K. (2005). Colony survivorship of social caterpillars in the field: A case study of the small Eggar moth (Lep., Lasiocampidae). J. Res. Lepidoptera 38, 15-25.

Ruf, C., Costa, J. T., and Fiedler, K. (2001). Trail-based communication in social caterpillars of Eriogaster lanestris (Lepidoptera: lasiocampidae). J. Insect Behav. $14,231-245$.

Ruf, C., Freese, A., and Fiedler, K. (2003). Larval sociality in three species of central-place foraging lappet moths (Lasiocampidae): a comparative survey. Zool. Anzeiger 242, 209-222. 
Ruxton, G. D., Allen, W. L., Sherratt, T. N., and Speed, M. P. (2019). Avoiding Attack: the Evolutionary Ecology of Crypsis, Aposematism, and Mimicry. Oxford: Oxford University Press.

Santana, A. F. K., McClure, M., Ethier, J., and Despland, E. (2015). Exploration costs promote conservative collective foraging in the social caterpillar Malacosoma disstria. Anim. Behav. 105, 245-250.

Schemske, D. (2009). Speciation and Patterns of Diversity. Cambridge: Cambridge University Press. 219-239.

Schoombie, R. E., Boardman, L., Groenewald, B., Glazier, D. S., Daalen, C. E., van, Clusella-Trullas, S., et al. (2013). High metabolic and water-loss rates in caterpillar aggregations: evidence against the resource-conservation hypothesis. J. Exp. Biol. 216, 4321-4325. doi: 10.1242/jeb.095554

Seymour, R. S. (1974). Convective and evaporative cooling in sawfly larvae. J. Insect Physiol. 20, 2447-2457. doi: 10.1016/0022-1910(74)90030-4

Stamp, N. E. (1980). Egg deposition patterns in butterflies: why do some species cluster their eggs rather than deposit them singly? Am. Nat. 115, 367-380.

Stamp, N. E., and Bowers, M. D. (1990). Variation in food quality and temperature constrain foraging of gregarious caterpillars. Ecology 71, 1031-1039.

Sun, J. J., and Underwood, D. L. A. (2011). Maintenance of sociality in a communal caterpillar, Eucheira socialis westwoodi (Lepidoptera: pieridae). Evol. Ecol. Res. $13,625-635$.

Sword, G. A. (1999). Density-dependent warning coloration. Nature 397, 217-217.

Terbot, J. W., Gaynor, R. L., and Linnen, C. R. (2017). Gregariousness does not vary with geography, developmental stage, or group relatedness in feeding redheaded pine sawfly larvae. Ecol. Evol. 7, 3689-3702. doi: 10.1002/ece3.2952

Traulsen, A., and Nowak, M. A. (2006). Evolution of cooperation by multilevel selection. Proc. Natl. Acad. Sci. 103, 10952-10955.

Tsubaki, Y., and Shiotsu, Y. (1982). Group feeding as a strategy for exploiting food resources in the burnet moth Pryeria sinica. Oecologia 55, 12-20. doi: 10.1007/BF00386712

Uemura, M., Zalucki, M., and Battisti, A. (2020). Behavioural plasticity and tree architecture shapes tent and foraging locations of pine processionary larval colonies. Entomol. Gener. 41, 121-136. doi: 10.1127/entomologia/2020/ 1091

Underwood, D. L. A., and Shapiro, A. M. (1999). Evidence for division of labor in the social caterpillar Eucheira socialis (Lepidoptera: Lasiocampidae). Behav. Ecol. Sociobiol. 46, 2221-2227.

Wellington, W. G. (1960). Qualitative changes in natural populations during changes in abundance. Can. J. Zool. 38, 289-314. doi: 10.1139/z60-036
West, S. A., Cooper, G. A., Ghoul, M. B., and Griffin, A. S. (2021). Ten recent insights for our understanding of cooperation. Nat. Ecol. Evol. 5, 419-430. doi: 10.1038/s41559-020-01384-x

Willmer, P. G. (1980). The effects of a fluctuating environment on the water relations of larval Lepidoptera. Ecol. Entomol. 5, 271-292. doi: 10.1111/j.13652311.1980.tb01150.x

Willmott, K. R., and Freitas, A. V. L. (2006). Higher-level phylogeny of the Ithomiinae (Lepidoptera: nymphalidae): classification, patterns of larval hostplant colonization and diversification. Cladistics 22, 297-368. doi: 10.1111/ j.1096-0031.2006.00108.x

Wilson, E. O. (1971). The Insect Societies. Cambridge: Belknap Press of Harvard University Press.

Young, A. M., and Moffett, M. W. (1979). Behavioral Regulatory Mechanisms in Populations of the Butterfly Mechanitis isthmia in Costa Rica: adaptations to Host Plants in Secondary and Agricultural Habitats (Lepidoptera: nymphalidae: ithomiinae). Dtsch. Entomol. Z. 26, 21-38. doi: 10.1002/mmnd.19790260104

Zolotuhin, V. V., Efimov, R. V., Anikin, V. V., Demin, A. G., and Knushevitskaya, M. V. (2012). Changes in the suprageneric classification of Lasiocampidae (Lepidoptera) based on the nucleotide sequence of gene EF-1 $\alpha$. Entmol. Rev. 92, 531-547. doi: 10.1134/S0013873812050065

Zuk, M. (2016). Temperate Assumptions: how Where We Work Influences How We Think. Am. Nat. 188, S1-S7. doi: 10.1086/687546

Conflict of Interest: The author declares that the research was conducted in the absence of any commercial or financial relationships that could be construed as a potential conflict of interest.

Publisher's Note: All claims expressed in this article are solely those of the authors and do not necessarily represent those of their affiliated organizations, or those of the publisher, the editors and the reviewers. Any product that may be evaluated in this article, or claim that may be made by its manufacturer, is not guaranteed or endorsed by the publisher.

Copyright ( $\odot 2021$ Despland. This is an open-access article distributed under the terms of the Creative Commons Attribution License (CC BY). The use, distribution or reproduction in other forums is permitted, provided the original author(s) and the copyright owner(s) are credited and that the original publication in this journal is cited, in accordance with accepted academic practice. No use, distribution or reproduction is permitted which does not comply with these terms. 